\title{
A sampler-incubator for studying zooplankton grazing and phytoplankton production
}

\author{
Oscar RAVERA* and Silvia SCOTTO \\ CNR Istituto Italiano di Idrobiologia, L.go Tonolli 50, 28922 Verbania Pallanza, Italy \\ *e-mail corresponding author: o.ravera@iii.to.cnr.it
}

\begin{abstract}
A new instrument to quantify the zooplankton grazing on phytoplankton and the phytoplankton growth is described. This instrument consists of two cylindrical chambers and a mechanical system for shutting, by a messenger both the chambers simultaneously. With this instrument the grazing may be evaluated by counting the algal cells at the beginning and the end of the experiment as well as by the radioisotope technique. This instrument combines the advantages of others used to the same aim by other authors; e.g. Gliwicz (1968), Haney (1971), Hart \& Christmas (1984). As an example, the results of two experiments are reported.
\end{abstract}

Keywords: grazing chamber, phytoplankton growth, zooplankton grazing, filtering rate, feeding rate, electivity coefficient

\section{INTRODUCTION}

The first experiments on the feeding of zooplankton were carried out by Fuller \& Clarke (1936), who measured the filtering rate of Calanus finmarchicus. Since then there have been several laboratory studies on zooplankton feeding. The feeding rate has generally been measured on the difference in abundance of the algae suspension used as zooplankton food, before and after the experiment. The feeding rate measurement has been improved by feeding zooplankters with particles (algae, bacteria, yeast) labelled with radioisotopes (Marshall \& Orr 1955; Nauwerck 1959; Sorokin 1966). Although the results from these studies increased our knowledge of potential zooplankton grazing, they cannot be easily extrapolated to the natural community. In fact, the feeding rate measured on the same species is deeply influenced by environmental variables such as quantity, quality and size of the food particles, light, temperature (e.g. Haney 1973; Peters 1984). In addition, the structure of the phyto- and zooplankton communities varies with the season and the environment. There was a clear need for a method producing results which could be extrapolated to the natural environment; that is, experiments in situ with grazing chambers (e.g., Haney 1971; Roman \& Rublee 1981; Lampert 1988; Noges 1992). The first approach was by Gliwicz (1968). The main advantage of grazing studies in situ is that the experiment is carried out in semi-natural conditions and at the same place and depth from which the material (zooplankton and its food particles) is collected. In addition, the experiment begins at the same time as, or soon after, collection of the material.

The grazing rate may be estimated by two different techniques: a) non-radioactive method and b) radioactive method.
The purpose of this paper is to describe a new sampler-incubator designed to estimate zooplankton grazing and at the same time the phytoplankton variation rate, in terms of cell number.

\section{DESCRIPTION AND USE OF THE SAMPLER- INCUBATOR (FIG. 1)}

The twin grazing chamber described here is based on the devices developed by Gliwicz (1968), Haney (1971) and Hart \& Christmas (1984).

The sampler-incubator consists of a firm frame, two cylindrical chambers (A and B) and a mechanical system for shutting both chambers simultaneously. The volume of the water contained in each closed chamber is 3 liters. The top and bottom of each chamber are shut by two lids hinged to the firm frame and not to the chambers, in order to keep the chamber openings completely unobstructed. The shutting device consists of a movable frame and four springs to release the lids. Each lower lid has a drain outlet closed by a plug. The movable and firm frames, the chambers and their lids are in Perspex, with only the shutting system in stainless steel. By a messenger the movable frame is lowered together with four pins, which release four rings attached to the lids. The four lids, released by the springs, hermetically and simultaneously close both the chambers. A glass vial is placed on a Perspex support soldered to the inner wall of chamber A.

The vial may be filled with an anaesthetising substance or a suspension of food particles labelled with radioisotopes. As the chambers are shut, a Perspex wedge soldered to the lower surface of the top lid of chamber A knocks against the vial, breaking it. The broken vial releases its content in the water of the chamber. The diffusion time of the liquid from the vial into the water in the chamber, estimated with a dye 


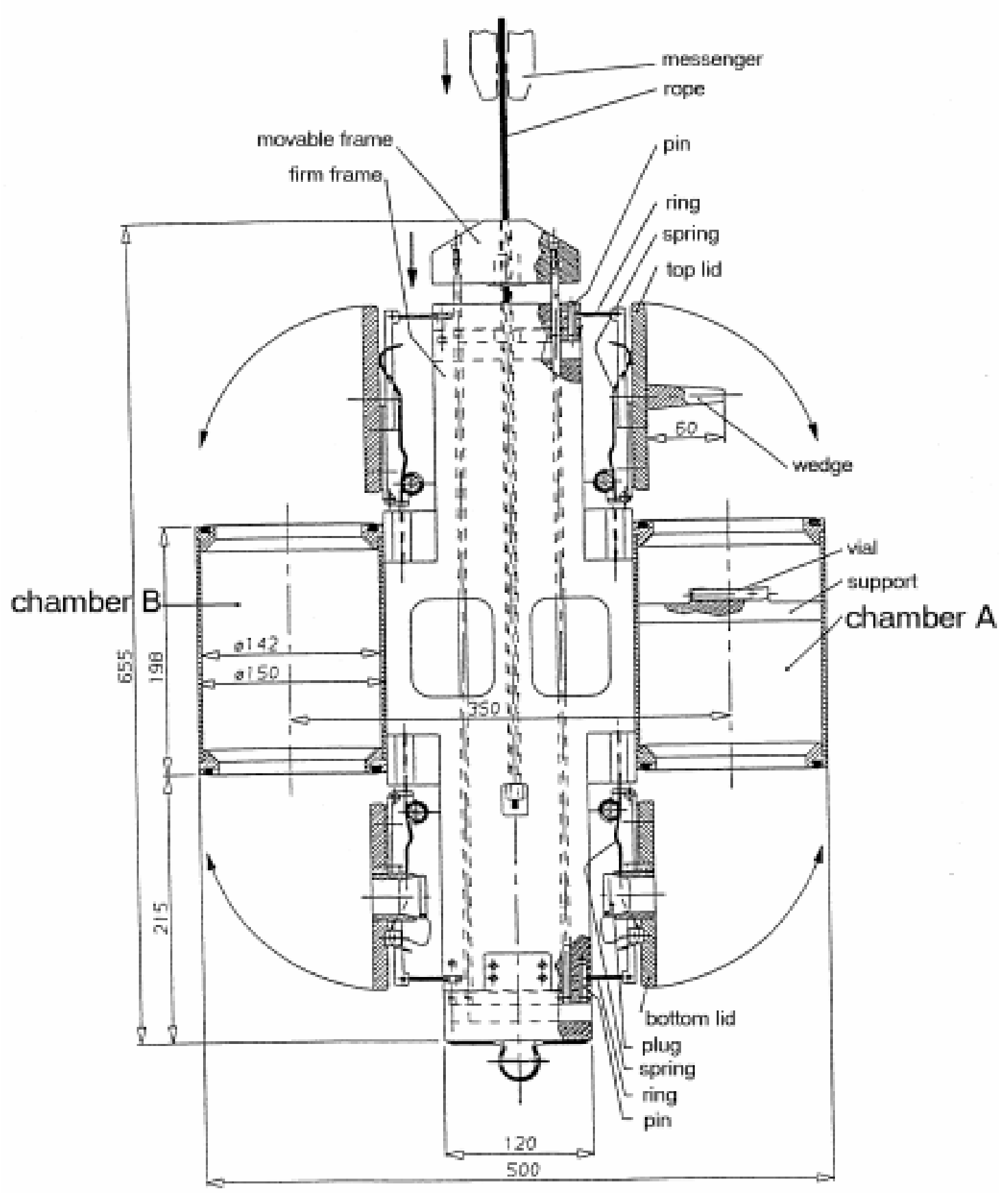

Fig. 1. Sampler incubator (see the text for further explanation).

(methylene blue), is less than one minute. This makes it possible to carry out experiments on grazing either with radioactive tracers (e.g., Haney 1971; Hart \& Christmas 1984) or anaesthetising substances (Gliwicz 1968). In addition, this sampler-incubator, slightly modified, may be used for the same purpose without radioisotopes or anaesthetising substances. The reliability of our device was tested by this technique, which is based on the dif- ference, measured at the end of the experiment, between the phytoplankton population density in the chambers with and without zooplankton (e.g., Elser \& Goldman 1990; Hamza et al. 1991).

First of all chamber A, without zooplankton but with a phytoplankton abundance very similar to that in the grazing chamber (B), that is with zoo- and phytoplankton, was needed. To this aim a disk of nylon net (mesh 
size $=60 \mu \mathrm{m})$ was attached inside chamber A near its lower edge. During the immersion of the device to the prefixed depth, the net permitted the passage of algae $<60 \mu \mathrm{m}$ size but not that of most of the zooplankters. In fact, the percentage of zooplankters found in the chamber with the net (A) ranged from 10 to $15 \%$ of the total number of zooplankters in the other chamber (B), consisting of small rotifers and nauplia $1^{\text {st }}$ and $2^{\text {nd }}$ stages. The number of phytoplankton cells in the two chambers was of the same order of magnitude.

The procedure was the following. The incubatorsampler with both chambers open was lowered to a given depth, immediately shut by a messenger and then recovered. Both the samples were preserved with neutralized formaldehyde at a final concentration of $10 \%$. Soon after the samples were recovered, the incubator sampler was again lowered to the same depth; the chambers were closed and kept for 4 hours at the same place. The time interval between the first recovery of the device and its successive lowering ranged from 10 to 15 minutes. To reduce the phytoplankton sedimentation inside the chambers the incubator sampler was upturned every hour by a supplementary rope. After 4 hours the apparatus was recovered and both the samples preserved with neutralized formaldehyde: phyto- and zooplankton of the four samples were identified and counted. Phytoplankton growth and zooplankton grazing were calculated from the differences in phytoplankton abundance between the first two samples and the samples collected at the end of the experiment. Growth rate, in terms of cell number, was estimated from the samples from chamber A and the grazing rate from those from chamber B. Since the difference in chamber B was the combined result of the growth and grazing rates, the grazing values were corrected for the phytoplankton growth rate.

\section{EXPERIMENTS}

The reliability of the adopted procedure was based on two assumptions: a) the quali- and quantitative differences between plankton samples collected by the two chambers ( $A$ and $B$ ) were not significative and $b$ ) the differences between samples collected at short intervals of time (10-15 minutes) and from the same place were not significative. To test these assumptions the nylon net was obviously removed from chamber $\mathrm{A}$ and the apparatus used as a twin water sampler.

To evaluate assumption a), samples from two northern Italian lakes (Lake Comabbio, very eutrophic, and Lake Monate, oligo-mesotrophic) were collected at different depths and dates and analyzed for phyto- and zooplankton (Tab. 1, 2 and 3). The data were processed according to Wilcoxon's test for paired comparisons to evaluate the difference between samples collected with both the chambers. The differences were always below the 0.05 significance level (except for Copepods from Lake Monate sampled at May $25^{\text {th }}$ ) and thus acceptable (Tab. 4). To evaluate assumption b) phyto- and zooplankton samples from the same depth and place and at an interval of $15 \mathrm{~min}$. were collected. Since the values of the variation coefficient were very low for zooplankton and not high for phytoplankton, the differences between replications at short time intervals seem to be acceptable (Tab. 5).

When sampling reliability had been tested, there was a need for experiments to evaluate the suitability of our

Tab. 1. Distribution with depth of the abundance $\left(\mathrm{N}^{\circ}\right.$ ind $\left.\mathrm{l}^{-1}\right)$ of Copepods $(\mathrm{Co})$, Cladocerans $(\mathrm{Cl})$ and Rotifers $(\mathrm{R})$ collected from Lake Comabbio with the chambers A and B.

\begin{tabular}{|c|c|c|c|c|c|c|c|c|c|c|c|c|c|c|c|c|}
\hline \multirow{3}{*}{$\begin{array}{c}\text { depth } \\
\text { (m) }\end{array}$} & \multicolumn{8}{|c|}{ May $31^{\text {st }}$} & \multicolumn{8}{|c|}{ July $18^{\text {th }}$} \\
\hline & \multicolumn{4}{|c|}{$\mathrm{A}$} & \multicolumn{4}{|c|}{$\mathrm{B}$} & \multicolumn{4}{|c|}{ A } & \multicolumn{4}{|c|}{ B } \\
\hline & Co & $\mathrm{Cl}$ & $\mathrm{R}$ & $\sum$ & Co & $\mathrm{Cl}$ & $\mathrm{R}$ & $\sum$ & Co & $\mathrm{Cl}$ & $\mathrm{R}$ & $\sum$ & Co & $\mathrm{Cl}$ & $\mathrm{R}$ & $\sum$ \\
\hline 1 & 36.3 & 133.6 & 64.0 & 233.9 & 26.7 & 136.5 & 73.7 & 236.9 & 207.6 & 70.6 & 9.0 & 287.2 & 201.6 & 86.1 & 6.9 & 294.6 \\
\hline 2 & 30.0 & 223.6 & 304.9 & 558.5 & 37.0 & 218.4 & 242.9 & 498.3 & 100.3 & 82.6 & 4.0 & 186.9 & 106.0 & 90.2 & 6.9 & 203.1 \\
\hline 3 & 21.7 & 153.6 & 209.9 & 385.2 & 20.6 & 146.1 & 169.7 & 336.4 & 110.0 & 112.6 & 25.6 & 248.2 & 124.1 & 102.9 & 31.2 & 258.2 \\
\hline 4 & 29.0 & 31.7 & 122.3 & 183.0 & 19.2 & 35.0 & 106.3 & 160.5 & 228.3 & 199.3 & 45.0 & 472.6 & 186.2 & 193.4 & 36.3 & 415.9 \\
\hline 5 & 95.0 & 3.3 & 96.3 & 194.6 & 115.2 & 1.7 & 91.9 & 208.8 & 3.3 & 0.3 & 0.0 & 3.6 & 2.1 & 0.3 & 0.0 & 2.4 \\
\hline 6 & 1.0 & 3.0 & 6.3 & 10.3 & 2.1 & 3.1 & 7.5 & 12.7 & 0.7 & 1.0 & 0.0 & 1.7 & 1.0 & 0.7 & 0.3 & 2.0 \\
\hline
\end{tabular}

Tab. 2. Distribution with depth of the abundance $\left(\mathrm{N}^{\circ}\right.$ ind $\left.\mathrm{l}^{-1}\right)$ of Copepods $(\mathrm{Co})$, Cladocerans $(\mathrm{Cl})$ and Rotifers $(\mathrm{R})$ collected from Lake Monate with the chambers A and B.

\begin{tabular}{|c|c|c|c|c|c|c|c|c|c|c|c|c|c|c|c|c|}
\hline \multirow{3}{*}{$\begin{array}{c}\text { depth } \\
\text { (m) }\end{array}$} & \multicolumn{8}{|c|}{ May $8^{\text {th }}$} & \multicolumn{8}{|c|}{ May $25^{\text {th }}$} \\
\hline & \multicolumn{4}{|c|}{ A } & \multicolumn{4}{|c|}{ B } & \multicolumn{4}{|c|}{ A } & \multicolumn{4}{|c|}{ B } \\
\hline & $\mathrm{Co}$ & $\mathrm{Cl}$ & $\mathrm{R}$ & $\Sigma$ & $\mathrm{Co}$ & $\mathrm{Cl}$ & $\mathrm{R}$ & $\Sigma$ & Co & $\mathrm{Cl}$ & $\mathrm{R}$ & $\Sigma$ & Co & $\mathrm{Cl}$ & $\mathrm{R}$ & $\Sigma$ \\
\hline 2 & 10.0 & 0.0 & 7.7 & 17.7 & 11.7 & 0.0 & 8.9 & 20.6 & 26.7 & 0.3 & 20.7 & 47.7 & 21.3 & 0.0 & 13.0 & 34.3 \\
\hline 4 & 31.0 & 9.3 & 16.0 & 56.3 & 36.4 & 5.1 & 24.0 & 65.5 & 16.0 & 0.0 & 7.7 & 23.7 & 13.7 & 0.0 & 24.3 & 38.0 \\
\hline 10 & 18.0 & 2.7 & 39.3 & 60.0 & 14.4 & 1.0 & 47.0 & 62.4 & 9.3 & 0.3 & 6.3 & 15.9 & 6.9 & 0.0 & 5.5 & 12.4 \\
\hline 15 & 3.3 & 4.3 & 6.3 & 13.9 & 9.3 & 4.1 & 22.3 & 35.7 & 10.3 & 0.7 & 9.0 & 20.0 & 8.9 & 0.7 & 7.5 & 17.1 \\
\hline 20 & 2.7 & 1.3 & 2.3 & 6.3 & 0.7 & 1.7 & 2.1 & 4.5 & 13.3 & 0.0 & 1.7 & 15.0 & 11.7 & 0.0 & 3.8 & 15.5 \\
\hline 25 & 3.7 & 1.0 & 1.3 & 6.0 & 1.4 & 0.3 & 3.4 & 5.1 & 8.7 & 0.3 & 1.3 & 10.3 & 4.1 & 0.3 & 3.1 & 7.5 \\
\hline
\end{tabular}


Tab. 2. Continuation.

\begin{tabular}{|c|c|c|c|c|c|c|c|c|c|c|c|c|c|c|c|c|}
\hline \multirow{3}{*}{$\begin{array}{l}\text { depth } \\
\text { (m) }\end{array}$} & \multicolumn{8}{|c|}{ June $8^{\text {th }}$} & \multicolumn{8}{|c|}{ June $12^{\text {th }}$} \\
\hline & \multicolumn{4}{|c|}{$\mathrm{A}$} & \multicolumn{4}{|c|}{ B } & \multicolumn{4}{|c|}{ A } & \multicolumn{4}{|c|}{ B } \\
\hline & Co & $\mathrm{Cl}$ & $\mathrm{R}$ & $\Sigma$ & Co & $\mathrm{Cl}$ & $\mathrm{R}$ & $\Sigma$ & Co & $\mathrm{Cl}$ & $\mathrm{R}$ & $\Sigma$ & Co & $\mathrm{Cl}$ & $\mathrm{R}$ & $\Sigma$ \\
\hline 2 & 14.3 & 0.3 & 15.7 & 30.3 & 13.4 & 0.7 & 12.7 & 26.8 & 44.0 & 7.0 & 3.0 & 54.0 & 43.2 & 7.5 & 3.8 & 54.5 \\
\hline 4 & 17.0 & 0.7 & 112.0 & 129.7 & 9.9 & 0.3 & 94.6 & 104.8 & 54.6 & 7.0 & 9.7 & 71.3 & 67.5 & 10.6 & 12.7 & 90.8 \\
\hline 10 & 33.0 & 1.0 & 20.6 & 54.6 & 37.0 & 0.0 & 22.6 & 59.6 & 80.0 & 3.7 & 33.0 & 116.7 & 75.1 & 0.3 & 30.9 & 106.3 \\
\hline 15 & 33.0 & 1.0 & 13.0 & 47.0 & 29.5 & 0.3 & 19.5 & 49.3 & 23.7 & 0.0 & 50.3 & 74.0 & 27.4 & 0.0 & 55.5 & 82.9 \\
\hline 20 & 16.0 & 0.3 & 5.0 & 21.3 & 26.4 & 0.3 & 4.8 & 31.5 & 34.3 & 0.0 & 11.0 & 45.3 & 38.7 & 0.0 & 11.0 & 49.7 \\
\hline 25 & 17.0 & 0.3 & 4.3 & 21.6 & 15.4 & 1.0 & 3.1 & 19.5 & 28.0 & 0.0 & 1.0 & 29.0 & 27.7 & 0.0 & 2.0 & 29.7 \\
\hline
\end{tabular}

Tab. 3. Distribution with depth of the abundance $\left(\mathrm{N}^{\circ}\right.$ cells $\left.\times 10^{3} 1^{-1}\right)$ of Cyanobacteria (Cya), Chlorophytae (Chl), Crysophytae (Cry), Bacillariophytae (Bac) and Dinophytae (Din) collected from Lake Monate with the chambers A and B.

\begin{tabular}{|c|c|c|c|c|c|c|c|c|c|c|c|c|}
\hline \multirow{3}{*}{$\begin{array}{c}\text { depth } \\
\text { (m) }\end{array}$} & \multicolumn{12}{|c|}{ July $8^{\text {th }}$} \\
\hline & \multicolumn{6}{|c|}{ A } & \multicolumn{6}{|c|}{ B } \\
\hline & Суа & Chl & Cry & $\mathrm{Bac}$ & Din & $\Sigma$ & Cya & Chl & Cry & $\mathrm{Bac}$ & Din & $\Sigma$ \\
\hline 1 & 350 & 1469 & 31 & 10 & 7 & 1867 & 301 & 1674 & 41 & 18 & 1 & 2035 \\
\hline 2 & 189 & 1446 & 34 & 7 & 3 & 1679 & 169 & 1482 & 37 & 11 & 3 & 1702 \\
\hline 3 & 155 & 838 & 95 & 67 & 6 & 1161 & 250 & 738 & 83 & 47 & 6 & 1124 \\
\hline 4 & 82 & 128 & 162 & 7 & 3 & 382 & 65 & 164 & 168 & 1 & 1 & 399 \\
\hline 5 & 78 & 55 & 121 & 0 & 1 & 255 & 83 & 49 & 119 & 0 & 1 & 252 \\
\hline 6 & 0 & 17 & 88 & 0 & 1 & 106 & 0 & 11 & 91 & 0 & 1 & 103 \\
\hline
\end{tabular}

Tab. 4. Values of the Wilcoxon test for paired comparisons $(\mathrm{T})$ were calculated on the data reported in table 1, 2 and 3 . Co = Copepods; $\mathrm{Cl}=$ Cladocerans; $\mathrm{R}=$ Rotifers. For total phytoplankton all the taxa have been taken in account; for the single taxon only the three most important were considered: Cyanophytae (Cya), Chlorophytae (Chl) and Cryptophytae (Cry).

\begin{tabular}{llcccccccc}
\hline Lake & Date & Co & $\mathrm{Cl}$ & $\mathrm{R}$ & $\mathrm{T}$ & Cya & Chl & Cry & $\mathrm{T}$ \\
\hline Monate & May 8 & 9 & 13 & 1 & 3 & - & - & - & - \\
& May 25 & 21 & 3 & 8 & 10.8 & - & - & - & - \\
& June 8 & 10 & 10 & 13 & 9 & - & - & - & - \\
& July 12 & 8 & 3 & 3 & 11 & - & - & - & - \\
\multirow{5}{*}{ Comabbio } & June 8 & - & - & - & 14 & 9 & 8 & 7 & 14 \\
& May 31 & 10.5 & 13 & 17 & 15 & - & - & - & - \\
& July 18 & 12 & 7 & 5 & 9 & - & - & - & - \\
\hline
\end{tabular}

Tab. 5. Mean values, standard deviations and percent ratio between standard deviation and mean value of the abundance of zooplankters $\left(\mathrm{N}^{\circ}\right.$ ind $\left.1^{-1}\right)$ and phytoplankters $\left(\mathrm{N}^{\circ}\right.$ cells $\left.\times 10^{3} 1^{-1}\right)$ collected by three samplings with chambers A and B from Lake Monate $(4 \mathrm{~m}$ depth).

\begin{tabular}{llccc}
\hline & & $\mathrm{A}$ & $\mathrm{B}$ & $\sum(\mathrm{A}+\mathrm{B})$ \\
\hline Zooplankton & Sampl. I & 43.6 & 43.7 & 87.3 \\
& Sampl. II & 42.7 & 45.5 & 88.2 \\
& Sampl. III & 45.3 & 44.3 & 89.6 \\
& $\overline{\mathrm{x}} \pm$ sd & $43.87 \pm 1.32$ & $43.90 \pm 0.44$ & $44.18 \pm 0.88$ \\
& \%sd/ $\overline{\mathrm{x}}$ & 3.01 & 1.00 & 2.00 \\
Phytoplankton & Sampl. I & 575 & 585 & 1160 \\
& Sampl. II & 603 & 661 & 1264 \\
& Sampl. III & 472 & 593 & 1065 \\
& $\overline{\mathrm{x}} \pm \mathrm{sd}$ & $550.00 \pm 69.00$ & $613.00 \pm 41.75$ & $581.50 \pm 61.59$ \\
& $\% \mathrm{sd} / \overline{\mathrm{x}}$ & 12.54 & 6.81 & 10.59 \\
\hline
\end{tabular}

method to quantify phytoplankton production and zooplankton grazing. As a consequence, two experiments were carried out in a Northern Italian oligo-mesotrophic lake, Lake Monate (4547'40" N; 08³9'52" W), with a surface of $2.51 \mathrm{~km}^{2}$ and a maximum depth of 34 meters. The experiments were carried out at $4 \mathrm{~m}$ depth and the incubation time was 4 hours. The procedure described above was adopted for our experiments: one on August 
$23^{\text {rd }}$ and the other on September $7^{\text {th }}$. During the incubation time, temperature, water transparency by Secchi disk, $\mathrm{pH}$ value, electrical conductivity and DO concentration were measured at the same depth and place where the incubator-sampler was anchored (Tab. 6).

Tab. 6. Physical and chemical parameters measured at the beginning and the end of the experiments carried out in Lake Monate (4 m depth) on August and September.

\begin{tabular}{lcccccc}
\hline & \multicolumn{2}{c}{ August } & & \multicolumn{2}{c}{ September } \\
\cline { 2 - 3 } \cline { 5 - 6 } \cline { 5 - 6 } time & 0 & $4 \mathrm{~h}$ & & 0 & $4 \mathrm{~h}$ \\
\hline Temp. ${ }^{\circ} \mathrm{C}$ & 26.2 & 27.4 & & 22.4 & 22.8 \\
$\mathrm{pH}$ & 9.69 & 9.62 & & 9.15 & 9.20 \\
$\mathrm{\mu S} \mathrm{25}{ }^{\circ} \mathrm{C}$ & 111 & 112 & & 115 & 112 \\
$\mathrm{mg} \mathrm{O}_{2} \mathrm{l}^{-1}$ & 10.69 & 10.75 & & 10.19 & 10.32 \\
Sat. O & $\%$ & 134 & 137 & & 120 & 123 \\
Secchi disk (m) & \multicolumn{2}{c}{5.20} & & \multicolumn{2}{c}{8.90} \\
\hline
\end{tabular}

The values of the phyto- and zooplankton countings of both the experiments are listed in tables 7 and 8 . These values have been processed to calculate the filtering rate (Gauld 1951), the feeding-rate (Holm et al. 1983), the phytoplankton growth-rate (Elser \& Goldman 1991) and the electivity-coefficient (Jacobs 1974).

In August phytoplankton population density (9131 cells $\mathrm{ml}^{-1}$ ) was 3.6 times higher than that in September (2519 cells $\mathrm{ml}^{-1}$ ). In August the most abundant species were Microcystis (45\%), Chlamydomonas (37\%) and Sphaerocystis (11\%), which altogether represented 93\% of the total phytoplankton; in September the most abundant were Chlamydomonas (41\%), Microcystis (22\%) and Tetraedron (18\%) to a total of $81 \%$.
In both the experiments these species also constituted the main portion of the zooplankton diet (Tabs 7 and 8). The value of the electivity coefficient $(\log Q)$ is based on the relationship between the frequency of a species in the diet and that of the same species in the environment. In August this coefficient was positive for Chlamydomonas and Sphaerocystis; in September the preference still existed for Chlamydomonas while for Sphaerocystis the electivity coefficient became negative. Negative values, indicating avoidance, were observed for Microcystis on both dates and for Tetraedron in September (Fig. 2). These differences between the months were probably due to the different phyto- and zooplankton compositions: in August Cladocerans were numerically dominant while in September Rotifers were the most abundant group. The filtering rate in August was $0.97 \mathrm{ml}_{\text {zooplankter }}{ }^{-1} \mathrm{~h}^{-1}$ and in September 5.49. The mean feeding rate was in August 7946 algae zooplankter $^{-1} \mathrm{~h}^{-1}$ and in September 12415 (Tab. 9). The mean phytoplankton growth rate was in August 0.016 algae $\operatorname{alga}^{-1} \mathrm{~h}^{-1}$ and in September 0.020 (Tab. 10).

\section{DISCUSSION AND CONCLUSIONS}

The relationship between zooplankton and its food is controlled by various physical and biological factors, and the ratios between the components of its diet (phytoplankton, bacteria, protozoa and organic suspended particles) vary with their availability and relative abundance and the zooplankton species (Gliwicz 1969). In addition, zooplankton selects its food particles according to their size and quality (e.g., Geller 1984; Lampert \& Taylor 1984).

Tab. 7. Abundance of phytoplankton species (No. cells $\times 10^{3} 1^{-1}$ ) in the tube with net (A) and without net (B) at the beginning of the experiment and after 4 hours. The experiments were carried out in Lake Monate (4 m depth) on August $23^{\text {rd }}$ and September $7^{\text {th }}$.

\begin{tabular}{|c|c|c|c|c|c|c|c|c|}
\hline & \multicolumn{4}{|c|}{ August $23^{\text {rd }}$} & \multicolumn{4}{|c|}{ September $7^{\text {th }}$} \\
\hline & \multicolumn{2}{|c|}{ A } & \multicolumn{2}{|c|}{ B } & \multicolumn{2}{|c|}{ A } & \multicolumn{2}{|c|}{ B } \\
\hline & 0 & $4 \mathrm{~h}$ & 0 & $4 \mathrm{~h}$ & 0 & $4 \mathrm{~h}$ & 0 & $4 \mathrm{~h}$ \\
\hline Anabaena spiroides & 5 & 9 & 8 & 4 & 4 & 5 & 4 & 3 \\
\hline Microcystis aeruginosa & 4090 & 4075 & 3486 & 3156 & 546 & 417 & 590 & 299 \\
\hline Total Cyanophytae & 4095 & 4084 & 3494 & 3160 & 550 & 422 & 594 & 302 \\
\hline Ankistrodesmus falcatus & 32 & 31 & 23 & 31 & 9 & 10 & 11 & 12 \\
\hline Chlamydomonas sp. & 3335 & 4104 & 2954 & 3027 & 1024 & 1341 & 1123 & 641 \\
\hline Chlorella sp. & 66 & 76 & 52 & 69 & 40 & 47 & 38 & 33 \\
\hline Cosmarium sp. & 54 & 80 & 48 & 31 & 20 & 16 & 18 & 16 \\
\hline Oocystis lacustris & 58 & 46 & 60 & 41 & 22 & 22 & 13 & 12 \\
\hline Scenedesmus bijugatus & 187 & 240 & 183 & 140 & 149 & 149 & 157 & 83 \\
\hline Sphaerocystis schröteri & 1037 & 714 & 1103 & 571 & 81 & 78 & 111 & 87 \\
\hline Staurastrum gracile & 0 & 1 & 0 & 0 & 0 & 0 & 0 & 0 \\
\hline Tetraedron minimum & 172 & 206 & 148 & 202 & 456 & 502 & 512 & 416 \\
\hline Total Chlorophytae & 4941 & 5498 & 4571 & 4112 & 1801 & 2165 & 1983 & 1300 \\
\hline Ceratium hirundinella & 0 & 1 & 1 & 0 & 0 & 0 & 0 & 1 \\
\hline Peridinium sp. & 3 & 5 & 2 & 3 & 1 & 4 & 2 & 3 \\
\hline Total Dinophytae & 3 & 6 & 3 & 3 & 1 & 4 & 2 & 4 \\
\hline Cryptomonas ovata & 40 & 63 & 41 & 45 & 65 & 63 & 71 & 43 \\
\hline Rhodomonas minuta & 52 & 87 & 65 & 50 & 102 & 79 & 97 & 53 \\
\hline Total Cryptophytae & 92 & 150 & 106 & 95 & 167 & 142 & 168 & 96 \\
\hline Total & 9131 & 9738 & 8174 & 7370 & 2519 & 2733 & 2747 & 1702 \\
\hline
\end{tabular}


Tab. 8. Abundance of zooplankton species $\left(\mathrm{N}^{\mathrm{o}}\right.$. ind $\left.\mathrm{l}^{-1}\right)$ in the chamber with net (A) and without net (B). The samples were collected from Lake Monate (4 $\mathrm{m}$ depth) on two separate days.

\begin{tabular}{|c|c|c|c|c|}
\hline & \multicolumn{2}{|c|}{ August $23^{\text {rd }}$} & \multicolumn{2}{|c|}{ September $7^{\text {th }}$} \\
\hline & $\mathrm{A}$ & $\mathrm{B}$ & $\mathrm{A}$ & $\mathrm{B}$ \\
\hline Eudiaptomus padanus adult and copepodite & 0.0 & 1.7 & 0.0 & 1.7 \\
\hline Eudiaptomus padanus nauplia & 0.7 & 5.5 & 0.0 & 4.1 \\
\hline Mesocyclops leuckarti adult and copepodite & 0.3 & 2.1 & 0.0 & 1.0 \\
\hline Mesocyclops leuckarti nauplia & 0.7 & 4.5 & 0.7 & 2.7 \\
\hline Total Copepods & 1.7 & 13.8 & 0.7 & 9.5 \\
\hline Eubosmina coregoni & 0.7 & 4.8 & 0.0 & 0.3 \\
\hline Daphnia hyalina & 1.0 & 2.1 & 1.7 & 3.8 \\
\hline Diaphanosoma brachyurum & 0.0 & 2.3 & 0.0 & 0.3 \\
\hline Total Cladocerans & 1.7 & 19.2 & 1.7 & 4.4 \\
\hline Asplanchna priodonta & 0.3 & 3.1 & 1.3 & 7.5 \\
\hline Keratella cochlearis & 0.0 & 0.0 & 0.0 & 0.7 \\
\hline Trichocerca capucina & 0.0 & 1.0 & 0.0 & 1.7 \\
\hline Filinia longiseta & 0.0 & 0.0 & 0.0 & 0.7 \\
\hline Total Rotifers & 0.3 & 4.1 & 1.3 & 10.6 \\
\hline Total & 3.7 & 37.1 & 3.7 & 24.5 \\
\hline
\end{tabular}
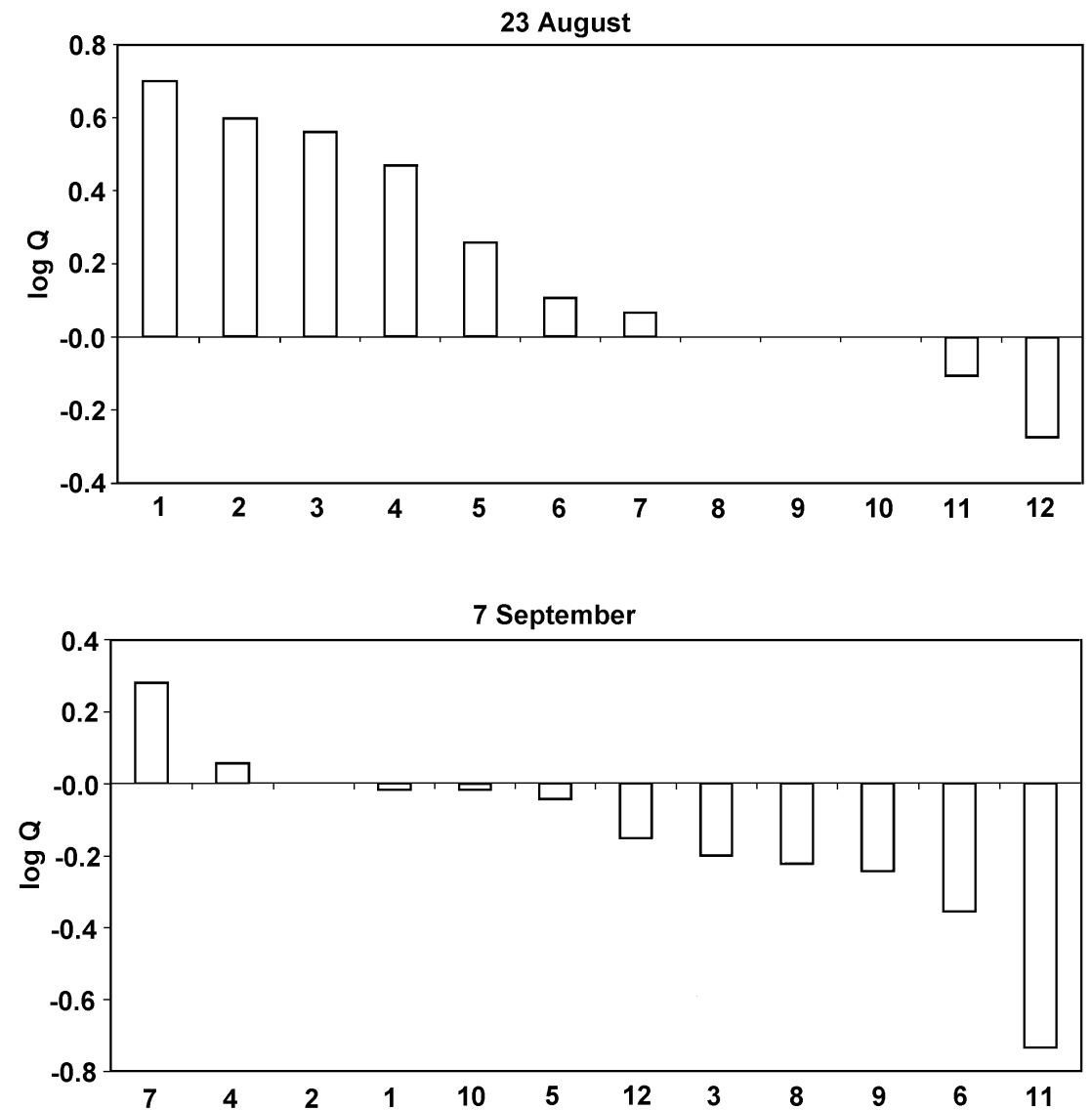

Fig. 2. Values of the electivity coefficient ( $\log$ Q) calculated for the most abundant species in August and September. 1) Anabaena spiroides; 2) Cosmarium sp.; 3) Rhodomonas minuta; 4) Scenedesmus bijugatus; 5) Cryptomonas ovata; 6) Sphaerocystis schröteri; 7) Chlamydomonas sp.; 8) Chlorella sp.; 9) Tetraedron minimum; 10) Peridinium sp.; 11) Oocystis lacustris; 12) Microcystis aeruginosa. 
Tab. 9. Feeding-rate: $\mathrm{N}^{\mathrm{o}}$ of algal cells consumed by one zooplankter in one hour.

\begin{tabular}{lcc}
\hline & August & September \\
\hline Chlamydomonas sp & 3639 & 8009 \\
Microcystis aeruginosa & 2136 & 1347 \\
Sphaerocystis schröteri & 809 & 202 \\
Scenedesmus bijugatus & 600 & 755 \\
Rhodomonas minuta & 323 & 196 \\
Cosmarium sp. & 243 & 0 \\
Cryptomonas ovata & 101 & 263 \\
Anabaena spiroides & 61 & 19 \\
Oocystis lacustris & 34 & 10 \\
Tetraedron minimum & 0 & 1482 \\
Chlorella sp. & 0 & 114 \\
Peridinium sp. & 0 & 18 \\
Total & 7946 & 12415 \\
\hline
\end{tabular}

Tab. 10. Algal increment (positive or negative): $\mathrm{N}^{\mathrm{o}}$ of algae produced (or decreased) per cell in one hour.

\begin{tabular}{|c|c|c|c|}
\hline \multicolumn{2}{|l|}{ August } & \multicolumn{2}{|c|}{ September } \\
\hline Anabaena spiroides & +0.15 & Peridinium $\mathrm{sp}$ & +0.35 \\
\hline Peridinium sp. & +0.13 & Chlamydomonas sp & +0.07 \\
\hline Rhodomonas minuta & +0.13 & Anabaena spiroides & +0.06 \\
\hline Cryptomonas ovata & +0.11 & Chlorella sp. & +0.04 \\
\hline Cosmarium sp. & +0.10 & Ankistrodesmus falcatus & +0.03 \\
\hline Scenedesmus bijugatus & +0.06 & Tetraedron minimum & +0.02 \\
\hline Chlamydomonas sp. & +0.05 & Oocystis lacustris & 0.00 \\
\hline Tetraedron minimum & +0.05 & Scenedesmus bijugatus & 0.00 \\
\hline Chlorella sp. & +0.04 & Sphaerocystis schröteri & -0.01 \\
\hline Microcystis aeruginosa & 0.00 & Cryptomonas ovata & -0.01 \\
\hline Ankistrodesmus falcatus & -0.01 & Cosmarium sp. & -0.06 \\
\hline Oocystis lacustris & -0.06 & Rhodomonas minuta & -0.06 \\
\hline Sphaerocystis schröteri & -0.09 & Microcystis aeruginosa & -0.07 \\
\hline
\end{tabular}

These considerations, along with the great variety of instruments and methods adopted to tackle the grazing problem, may explain the wide variations in the results reported by different authors (e.g., Lampert 1988; James \& Forsyth 1990; Noges 1992). For example, Gliwicz (1968) obtained filtering rate values as much as 15 times higher than those reported by other authors, the values found by Hart (1984) were very high if compared to those by Gulati et al. (1982), and the data on the filtering and feeding rates reported by Hamza et al. (1991, 1993) and Bonacina \& Hamza (1997) seem to be rather low.

The adoption of standardized methods would probably make it easier to compare the results obtained by the various authors. If this is not possible, then more research is required to compare results obtained at the same time and in the same environment with both techniques (radioactive and non-radioactive), with the aim of harmonizing the methods.

The main conclusions of the experiments we carried out in August and September in Lake Monate are the following. In August, phytoplankton and zooplankton were more abundant than in September (phytoplankton by $72 \%$ and zooplankton by $34 \%$ ). Conversely, the filtering and feeding rates were lower in August $(0.97 \mathrm{ml}$ ind $^{-1} \mathrm{~h}^{-1}, 7946$ cells ind $\left.{ }^{-1} \mathrm{~h}^{-1}\right)$ than in September (5.49 ind $^{-1} \mathrm{~h}^{-1} ; 12416$ cells ind $\left.{ }^{-1} \mathrm{~h}^{-1}\right)$. These differences are not easily explained; however, the values we calculated are of the same order of magnitude as those reported by other authors for freshwater and marine planktonic crustaceans. For example, the values of the filtering rate $\left(\mathrm{ml} \mathrm{ind}^{-1} \mathrm{~h}^{-1}\right.$ ) may range from 3.1 to 3.9 (Harvey 1937), from 0.35 to 2.92 (Gauld 1951) in relation to the size of the species, about 4.00 (Frost 1972) and from 0.62 to 1.15 (Holm et al. 1983). A feeding rate of 12.000 cells ind $^{-1} \mathrm{~h}^{-1}$ was calculated for copepods by Frost (1972), and values ranging from 15.000 to 50.000 cells ind ${ }^{-1} \mathrm{~h}^{-1}$ were reported by Holm et al. (1983) for Cladocerans kept in optimal conditions. According to Frost (1972) the ingestion rate increases with the concentration of food particles in the medium up to a maximum level and then remains fairly constant at a further increase in particle concentration.

In our experiment the ratio between the amount of algal cells grazed by zooplankton and the number of algal cells produced was $132 \%$ in August and $489 \%$ in 
September. These high percentages seem to demonstrate the strong influence exerted by zooplankton on phytoplankton. On the other hand, we must take into account the fact that the value of these percentages refers only to two months; in spite of this, these high percentages do not seem to be so exceptional if Gulati et al. (1982) calculated mean annual values ranging from 70 to $230 \%$. According to these authors the grazing activity has such a great influence on the phytoplankton standing crop as to increase the water transparency for limited periods of the year. This influence is also demonstrated indirectly by Gliwicz (1968), who calculated that zooplankton may consume daily an amount of food ranging from $48 \%$ to $176 \%$ of its biomass according to the lake, season and other factors.

The results of our experiments, which were carried out only twice (August and September), obviously cannot provide useful information for evaluating the actual importance of grazing and primary production in the studied lake. The aim of our experiments was simply to test the usefulness of the sampler-incubator, which has the following advantages.

- The experiment is carried out in the same chambers as are used as a sampler and consequently the phytoand zooplankton are not removed from their environment before the end of the experiment.

- Sample variability is reduced by collecting two samples simultaneously from the same place.

- The net (60 $\mu \mathrm{m}$ mesh size) soldered to the chamber for measuring the algal growth eliminates the zooplankton grazing without using anaesthetizing substances (Gliwicz 1968) or sieving the sample after removal from its environment (e.g., Porter 1972).

- There are no metal parts inside the chambers.

- The container and piston for dispensing anaesthetizing substances (or the radioactive food particles) have been replaced by a glass vial broken by the shutting of the chambers.

- Both methods (radioactive and non-radioactive) may be used.

- The acute effect of pollutants on phyto- and zooplankton in semi-natural conditions may be evaluated using one chamber as a control and the other as an environment contaminated by a pollutant diffused from the broken vial.

In conclusion, we believe that our sampler-incubator is useful for quantifying zooplankton grazing and primary production, in terms of algal cell abundance. The modifications incorporated in our instrument represent an improvement, or at least an alternative, to the commonly used devices.

\section{AKNOWLEDGMENTS}

We are grateful to Dr. R. de Bernardi, Dr. C. Callieri and Dr. G. Giussani for the helpful suggestions to ameliorate this manuscript.

\section{REFERENCES}

Bonacina, C. \& W. Hamza. 1997. Field observations on zooplankton grazing efficiency in an urban reservoir (Lake Bubano, N. Italy). Verh. int. Ver. Limnol., 26: 446-450.

Elser, J.J. \& C.R. Goldman. 1990. Experimental separation of the direct and indirect effects of herbivorous zooplankton in a subalpine lake. Verh. int. Ver. Limnol., 24: 493-498.

Elser, J.J. \& C.R. Goldman. 1991. Zooplankton effects on phytoplankton in lakes of contrasting trophic status. Limnol. Oceanogr., 36: 64-90.

Frost, B.W. 1972. Effects of size and concentration of food particles on the feeding behaviour of the marine planktonic copepod Calanus pacificus. Limnol. Oceanogr., 17: 805- 815.

Fuller, J.L. \& G.L. Clarke. 1936. Further experiments of the feeding of Calanus finmarchicus. Biol. Bull. Woods Hole, 70: 308-320.

Gauld, D.T. 1951. The grazing rate of planktonic copepods. $J$. Mar. Biol. Assoc. U.K., 29: 695-706.

Geller, W. 1984. A device for the in situ measurement of zooplankton food selection, grazing and respiration rates. Verh. int. Ver. Limnol., 22: 1425-1431.

Gliwicz, Z.M. 1968. The use of anaesthetizing substance in studies on the food habits of zooplankton communities. Ekol. Pol., 16: 279-295.

Gliwicz, Z.M. 1969. Studies on the feeding of pelagic zooplankton in lakes with varying trophy: Ekol. Pol., 17: 663708.

Gulati, R.D., Siewertsen, K. \& G. Postema. 1982. The zooplankton: its community structure, food and feeding, and role in the ecosystem of Lake Vechten. Hydrobiologia, 95:127-163.

Hamza, W., Giussani, G. \& D. Ruggiu. 1991. Observations on zooplankton grazing in a small biomanipulation lake (Lago di Candia, N-Italy) with the use of a simple in situ technique. Mem. Ist. ital. Idrobiol., 48: 149-161.

Hamza, W., Ruggiu D. \& M. Manca. 1993. Diel zooplankton migrations and their effect on the grazing impact in Lake Candia (Italy). Arch. Hydrobiol. 39: 175-185.

Haney, J.F. 1971. An in situ method for the measurement of zooplankton grazing-rate. Limnol. Oceanogr. 16: 970-976.

Haney, J.F. 1973. An in situ examination of the grazing activities of natural zooplankton communities. Arch. Hydrobiol., 72: 87-132.

Hart, R.C. 1984. Zooplankton community grazing in silt-laden Lake le Roux, Orange River, South Africa. Verh. int. Ver. Limnol., 22: 1602-1607.

Hart, R.C. \& G.L. Christmas. 1984. A twin Gliwicz-Haney in situ zooplankton grazing chamber: design, operation and potential applications. J. Plankton Res., 6: 715-719.

Harvey, H.W. 1937. Note on selective feeding by Calanus. J. Mar. Biol. Assoc. U.K., 22: 97-100.

Holm, N.P., Ganf, G.G. \& J. Shapiro. 1983. Feeding and assimilation rate of Daphnia pulex fed Aphanizomenon flosaquae. Limnol. Oceanogr., 28: 677-687.

Jacobs, J. 1974. Quantitative measurement of food selection. A modification of the Forage ratio and Ivlev's Electivity Index. Oecologia (Berlin), 14: 413-417.

James, M.R. \& D.J. Forsyth. 1990. Zooplankton-Phytoplankton interactions in a eutrophic lake. J. Plankton Res., 12: 455-472.

Lampert, W. \& B. Taylor. 1984. In situ grazing rates and particles selection by zooplankton: Effects of vertical migration. Verh. int. Ver. Limnol., 22: 943-946.

Lampert, W. 1988. The relationship between zooplankton biomass and grazing: a review. Limnologica, 19: 11-20.

Marshall, S.M. \& A.P. Orr. 1955. On the biology of Calanus finmarchicus. VIII. Food uptake, assimilation and excretion in adult and stage V Calanus. J. Mar. Biol. Assoc. U.K., 34: 495-529. 
Nauwerck, A. 1959. Zur Bestimmung der Filtrierrate limnischer Planktontiere. Arch. Hydrobiol. (suppl.), 25: 83-101.

Noges, T. 1992. Comparison of two methods of zooplankton grazing measurements. Int. Revue ges. Hydrobiol., 77: 665-672.

Peters, R.H. 1984. Methods for the study of feeding, grazing and assimilation by zooplankton. In: Downing, J.A. \& F.H. Rigler (Eds), A manual of methods for the assessment of secondary productivity in freshwaters. IBP Handbook 17, Blackwell Scientific Publications, Oxford.
Porter, K.G. 1972. A method for the in situ study of zooplankton grazing effects on the algal species composition and standing crop. Limnol. Oceanogr., 17: 913-917.

Roman, M.R. \& P.A. Rublee. 1981. A method to determine in situ zooplankton grazing-rates on natural particles assemblages. Mar. Biol., 65: 303-309.

Sorokin, J.I. 1966. Carbon-14 method in the study on the nutrition of aquatic animals. Int. Rev. Ges. Hydrobiol., 51: 209-224.

Received: November 1998

Accepted: January 1999

\section{APPENDIX}

The formulas used were the following:

1) Filtering-rate

$K=\frac{v}{t} \times \frac{\log C_{0}-\log C_{t}}{\log e} \quad$ (ml of water swept clear by one zooplankter in a time unit).

2) Feeding-rate

$F=\frac{v}{t} \times\left(C_{0}-C_{t}\right) \quad$ (No. of algae consumed by one zooplankter in a time unit).

3) Algal growth-rate

$G=\left(\ln \frac{C_{t}}{C_{0}}\right) \times t^{-1} \quad$ (No. of algae produced by one alga in a time unit).

4) $\log \mathrm{Q}$-coefficient

$\log$ Qcoefficient $=\frac{r(1-p)}{p(1-r)} \quad$ (modified version of Ivlev's Electivity Index $)$.

where: $v=$ water volume of the chamber. No. zooplankters ${ }^{-1}$.

$t=$ duration of the experiment in hours.

$C_{0}$ and $C_{t}=\mathrm{No} \cdot \mathrm{ml}^{-1}$ at the beginning and the end of the experiment.

$r=$ fraction of a given food type in the feeder's ration.

$p=$ fraction of the same food in the environment. 